\title{
Network Structure of Insurgent Groups and the Success of DDR Processes in Colombia
}

Ernesto Cardenas ${ }^{\mathrm{a}}$, Kristian Skrede Gleditsch ${ }^{\mathrm{b}}$ and Luis Carlos Guevara ${ }^{\mathrm{c}}$

${ }^{a}$ Associate Professor, Facultad de Ciencias Económicas y Administrativas Pontificia Universidad Javeriana Cali. Address: Calle 18 No 118 - 250 Cali, Colombia. Email: ernesto.cardenas@javerianacali.edu.co; ${ }^{b}$ Regius Professor of Political Science, Department of Government, University of Essex \& Research Associate, Peace Research Institute Oslo (PRIO). Email: ksg@essex.ac.uk; ${ }^{c}$ Universidad Externado de Colombia. Email: luis.guevara@uexternado.edu.co 


\section{Network Structure of Insurgent Groups and the Success of DDR Processes in Colombia}

We argue that organizational structure of insurgent organizations influences the prospects for success in a disarmament, demobilization, and reintegration process (DDR). In concrete, we argue that more cohesive, tighter, networks have higher levels of supervision and control on its military units and increase the probability of successful DDR processes. In order to evaluate our hypotheses, we use the theory of networks to map and characterize the network structure of the United Self-Defense Forces of Colombia (AUC) and the Revolutionary Armed Forces of Colombia (FARC). Our results suggest that armed military units grouped in smaller and more isolated components on the network remilitarize with higher probability with respect to other units on the network. Also, we find that military units with high degree of centrality on the network play an important role for the risk of conflict recurrence and success in a DDR process.

Keywords: Network structure; insurgent actors; DDR; Colombia.

\section{Introduction}

Most research on disarmament, demobilization and reintegration (DDR) focuses on the interaction between the government and the rebel group as individual agents, or study how ex-combatants' socio-economic characteristics affect the prospects for reintegration to civilian life. ${ }^{1}$ The first approaches have a clear macro focus, treating organizations as unitary actors, while the second type emphasizes entirely the microlevel, disregarding organizations or relations. Here we focus on an intermediate level i.e. the network structure of an insurgent group and its relation to the success of a DDR process. By the network structure of an insurgent group we mean the existing links between the different military units that together form the rebel group, and by successful DDR process we mean the absence of remilitarization of military units of a demobilized insurgent group. 
There are many reasons to believe that the structure of insurgent groups can be relevant for the study of civil wars in general and DDR processes in particular. For instance, the relative strength of rebel groups, both in their ability to inflict costs on a government and the ability to resist government repression, is found to be an important determinant of the duration of civil wars. ${ }^{2}$ Zukerman $^{3}$ analyzes the structure of the recruitment process in rebel groups, and finds that the geography of this process determines the probability for organized violence to reappear after the ending of civil wars. She classifies armed groups as local or non-local depending on whether they recruit people from the same zone where they performed activities or not. She argues that regions where all demobilized groups are local have higher probability for demilitarization of armed groups over time compared to regions where demobilized groups are local and non-local. Yet, none of the previous studies have focused on the properties of the rebel group's network structure per se and its relationship with the success of DDR processes.

Why does the network structure of a rebel group matter for the success of DDR processes? We believe that a DDR process can take advantage of the network structure to maintain communication and control among demobilized military units and/or excombatants and ensure commitment towards demobilization. Thus, the role of central units on the network and the structure of the network itself becomes important. Central military units can easily reach and pass information to other units on the network and tighter networks have more control over its members. Hence, knowledge about the network structure of the insurgent group and the centrality of its military units on the network increases the probability of success of a DDR process.

Mapping the network structure of an insurgent group also allows the identification of isolated military units or sub-networks that may need special treatment 
during the process due to its relative independence from other structures on the network. A map of the structure of a rebel group can help reveal salient attributes that must be incorporated when designing a DDR process, and indicate how different positions in network structures may require different types of treatments and interventions in DDR processes.

In this manuscript, we analyze the network structure of the United Self-Defense Forces of Colombia (AUC) and the Revolutionary Armed Forces of Colombia (FARC) and the implications for DDR success. For the AUC, we can compare the predictions of our theoretical framework with the eventual success in the DDR process underway. For the FARC, we do not as of the time of writing have a formal DDR process, but we can compare the implications of the network structure for likely DDR success, and compare our theoretical predictions with other expert assessments about the likely spoilers in a DDR process.

The AUC and the FARC have different origins and notably divergent network characteristics. AUC originates from the self-defense and paramilitary groups that emerged in the 1980s, based on the needs of rural landlords and drug cartels to protect from extortion by the guerrillas. In the beginning, these groups did not have a strong central command, nor a strong or cohesive ideological foundation. Rather, they mostly emerged as effective private armies for hire. In fact, not until the late 1997 did these self-defense groups coalesce as a more formal organization through the AUC, a united group with some command structure and right wing ideology.

By contrast, the origins of the FARC can be traced back to 1964, when the group launched an insurgency against the Colombian government with a self-professed communist ideology. From the outset, the FARC was an organized and unified group of guerrillas with clear political ideology and a well defined hierarchical structure as stated 
in the Agrarian Program of the Guerrillas, signed at what was called the First Guerrilla Conference in 1964.

We acknowledge that incentives and opportunities given to ex-combatants through a DDR process can modify the subsequent network structure of the group over time. However, these benefits and opportunities for ex-combatants do not appear immediately after the end of an armed confrontation and will take some years to materialize. Thus, we think it is valuable to consider as a first step how the network structure existing at the time that an insurgent group decides to end armed confrontation may influence the incentives of individual units.

\section{Networks and the success of DDR processes}

There is a growing body of research on the importance of networks in determining social and economic outcomes. ${ }^{4}$ In general, this literature considers either the role of a given network in affecting outcomes, a static problem, or the formation or evolution of networks, a dynamic problem. In international relations, for example, network theory has been used to understand properties of the structure of international systems and interaction patterns, ${ }^{5}$ the consequences of network structure for conflict and cooperation, ${ }^{6}$ or the evolution of particular networks such as international trade over time. ${ }^{7}$ However, there has been much less attention to networks in the study of domestic conflict.

In this manuscript, we focus on the role of the existing network structure of the AUC and that of the FARC into the success of their respective DDR processes. In particular, we concentrate on how the network structure affects the probability of rearmament of the military units on the network through its capacity for communication and supervision on its military units. We argue that more cohesive, tighter, networks 
have higher levels of supervision and control on its military units and increase the probability of successful DDR processes.

Here, we map the network structure of the AUC and the FARC, and compute some basic descriptive statistics associated with the properties of the network as a whole. Then, we analyze how these properties affect remilitarization of demobilized groups. Our first two hypotheses pertain to the general form of the network of the group and their capacity to exert supervision and control on its military units. We believe that tighter networks should higher capacity for communication and control over its military units in ways that will increase the probability of success in a DDR processes. We are implicitly assuming that insurgent groups that participate in DDR processes have incentives to genuinely pursue peace. Within a network, more isolated units should be more likely to act independently and be less constrained by the central command. We analyze how these properties affect remilitarization of demobilized groups by empirically testing the following theoretical hypotheses:

H1: We expect more cohesive insurgent groups to have a lower probability to remilitarize because of the greater monitoring capacity and coercive power they can exert among their military units.

H2: We expect isolated military units and smaller components in the network to have a higher probability to remilitarize because of the reduced monitoring capacity and coercive power that other military units can exert on them.

To test these hypotheses, we look at the overall clustering coefficient, the mean of degree, and the number of components of the network (these concepts are defined in the next section). Higher values of the clustering coefficient and of the mean of degree imply tighter, more cohesive, networks. With respect to the number of components, a 
network with more (less) components with respect to another is considered as less (more) cohesive.

The next two hypotheses deal with the position of individual military units on the network and their incentives to remilitarize. In particular, we expect to see a process of influence or diffusion from central units, as well as higher incentives to remilitarize for units that are likely to profit from drug trafficking.

H3: Military units with high levels of centrality in the network can positively affect the success of the DDR process if they do not remilitarize.

H4: Military units in isolated or smaller components and working on well identified areas associated to the drug trafficking business have higher probability to remilitarize.

For assessing H3 we use the betweenness and degree coefficients for each node in order to identify the most central nodes in the network. If the resulting central military units in the network do not remilitarize, then, we expect that military units in their same network components do not to remilitarize.

For assessing H4 we consider the characteristic of each military unit of the rebel groups operating in zones that are well known to be related with drug production or drug trafficking. Then we calculate the assortative coefficient for different attributes of each military unit. We expect networks with higher assortative coefficients on drug production/trafficking to be more likely to remilitarize.

\section{Theoretical Framework}

We use network theory to map the network structure of the AUC and the FARC. The theory of networks provides a set of concepts and techniques for analyzing the structure of relations between different individuals or groups. The establishment and graph visualization of such relations among the members of a specific structure allows, for 
example, to identify informal communication channels, substructures within a larger structure, as well as members, which may be of key strategic importance within the structure due to their privileged location inside it. A network is composed of a set of nodes, representing the analysis units that make up the structure under study, and of a set of links that connect such nodes, representing the relationships among them. Links may indicate, if necessary, the type or direction of a relationship (unidirectional or bidirectional), or even be weighted by a specific factor indicating the relative importance of that relationship within the total set of possible relationships.

Formally, a network is represented by a graph $N=(N, \boldsymbol{g})$, where $N=$ $\left(i_{1}, \ldots, i_{n}\right)$ is a set of nodes and $\boldsymbol{g}$ is an $n x n$ adjacency matrix on the set of nodes. Each entry, $g_{i j}$ in the adjacency matrix indicates the relationship between nodes $i, j$. If $g_{i j} \neq g_{j i}$ then the network is directed and if $g_{i j}=g_{j i}$ then the network is undirected. In our case, nodes represent military units of the insurgent groups. Military units are understood as operative groups that perform military actions within a defined territory. According to this definition, and restricted by the relevant information to map the network, we consider blocks as the relevant military unit for the case of the AUC and Fronts for the case of the FARC. In each case these are military bodies that gather together multiple columns, smaller military units, and have relative independence within the general command and control structures. This independence suggests, in addition to non-supervised relationships among them, that they can play role as spoilers, a relevant characteristic to be consider when dealing with DDR. ${ }^{8}$

The links on the inferred network represent existing communication between the two military units connected. We refer to them as links of shared departmental presence. We register a link of shared departmental presence between two nodes if both performed military activities in the same territory. Even if military units may be 
associated with or originally confined to specific geographical territories, the existing data on their military activities also reveal that many units in practice often attack in different places in different departments. We assume that if two units are present in the same territories then this implies that there must be some minimum level of coordination to perform military duties. Such active cooperation in turn implies information flows in both directions between the two nodes. In other words, a link of shared departmental presence between two nodes $i$ and $j$ implies a bidirectional relationship where information flows both from $i$ to $j$ and from $j$ to $i$.

\section{Density measures}

Density measures are relevant to the extent that they can affect the information transmission process or the capacity to enforce and monitor behaviors between the network.

Clustering is a measure of the frequency with which transitive relationships between nodes exist in a network $N=(N, \boldsymbol{g})$. Transitivity means that if node $i$ is linked to node $\mathrm{j}$, and $j$ is linked to $k$, then $i$ is linked to $k$.

The clustering coefficient of node $j, \operatorname{cl}(j)$ is defined as:

$$
c l(j)=\frac{\sum_{k \in N_{j}(g), i \in N_{j}(g), k \neq i} g_{i k}}{\sum_{k \in N_{j}(g), i \in N_{j}(g), k \neq i} g_{i k} g_{j i}}
$$

The index calculates the existing number of connected triads over the total number of possible triads on the network.

The average degree on a network give us some idea of the density of the connections in a network and is calculated as $\sum_{i} d_{i}(\boldsymbol{g}) / n$, which is just the average of the degree of all nodes on the network. 


\section{Centrality Measures}

The degree of a node is the number of connections that a node has with other nodes in a network. The degree of a node $i, d_{i}(g)$, is the number of neighbors that $i$ has in the network $N=(N, \boldsymbol{g})$, so that $d_{i}(g)=\left|N_{i}(\boldsymbol{g})\right|$ where $N_{i}(\boldsymbol{g})=\{j \mid i j \in g\}$ denotes the neighbors of a node $i$. Betweenness help us to gain intuition about how central a military unit is. It measures for each pair of other military units on what fraction of the total number of shortest paths between the two the given military unit lies. It is defined as:

$$
b t(k)=\frac{\sum_{i j: i \neq j, k \notin\{i, j\}} g_{i k}}{(n-1)(n-2) / 2}
$$

\section{Individual Characteristics}

Here we are interested in measures related to how links that we observe depend on other idiosyncratic characteristics of the nodes. In our case, we are interested in measuring to which extent links between military units depend on the fact of performing activities in well recognized regions affected by drug production/trafficking activities.

The assortativity coefficient measures to what extent nodes in a network connect with other nodes because of having the same individual characteristic. For instance, it is common in social networks that nodes become more likely to connect to each other because they share the same attributes. Formally, the assortativity coefficient is the Pearson correlation coefficient of the degrees at either ends of an edge and ranges between $[-1,1] .^{9}$

\section{Data}

Information about demobilized blocks of the AUC as well as other relevant 
characteristics such as the size of each block, in terms of combatants, and the geographical areas where they operated is taken from Oficina del Alto Comisionado para la Paz [Office of the High Commissioner for Peace]. ${ }^{10}$ Information about remobilized blocks comes from Zukerman. ${ }^{11}$

For the FARC, we rely on two main sources of information; the Centro Nacional de Memoria Histórica, CNMH [National Center for Historical Memory] ${ }^{12}$ and the Observatorio de Procesos de Desarme, Desmobilización y Reintegración, ODDR [Observatory of Disarmament, Demobilization, and Reintegration Processes]. ${ }^{13}$

The CNMH, based on the bylaws of the FARC, a document published by the guerilla itself, makes the ideological foundations of the guerilla explicit, and defines the organizational structure, command regime and duties and rights of combatants. In terms of information, one of the more valuable resources extracted from the Bylaws is the hierarchical structure of the FARC, which is centered on the head of the Central Major State (CMS) and its secretariat, and defines the structure of sub-ordinate units and chain of command that should be followed by the military corps of the guerilla.

On the other hand, the information on departmental presence of the FARC in 2012 was obtained from monitoring, studying, and applied analysis of the testimonies of demobilized individuals, institutional sources, communications, and war reports published by the guerilla, as well as the revision of media through the Sistema Actualizado de Información, SAI [Updated Information System], carried out by the ODDR. This is the only study with disaggregated information for the FARC at the level of individual fronts, our unit of analysis. The information available is discriminated by hierarchical structures, and there are in total records of presence in 30 departments of: 7 blocks, 73 fronts, 18 columns, 31 companies, 1 mobile block, and 1 unit. 


\section{Results}

\section{Network Structure and Remilitarization of the AUC}

We start by testing hypotheses $\mathrm{H} 1$ and $\mathrm{H} 2$, arguing that more cohesive insurgent groups should be less likely to remilitarize and that more isolated military units and smaller components in the network have a higher probability to remilitarize. Figure 1 shows the network structure for the AUC, based on the attribute of shared departmental presence for their military units as explained above.

Figure 1. AUC’s shared departmental presence network (gray nodes indicate remilitarized military units)

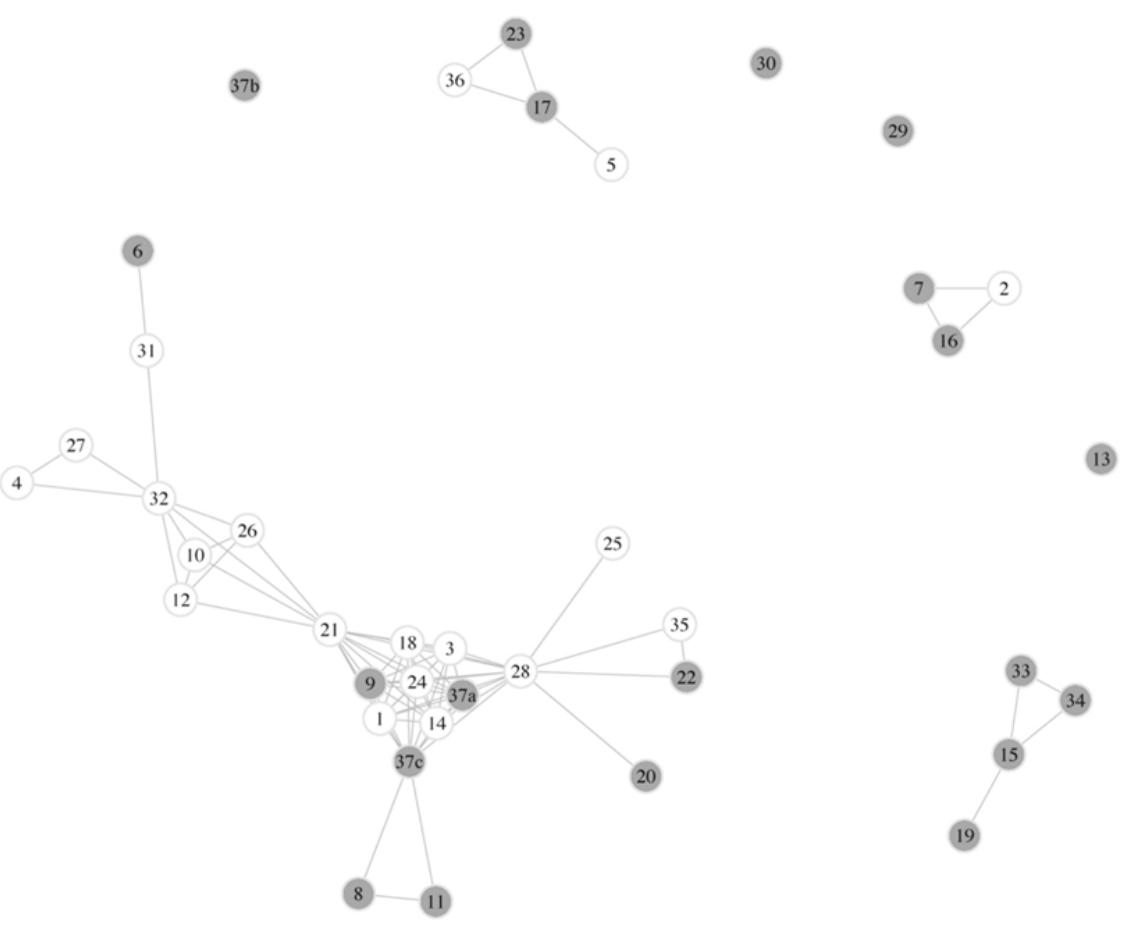

A visual inspection of the graph tells us that the network is composed by 8 components of different sizes. This suggests a not-so-tight network, despite the principal component having 24 of the total 39 blocks on the network. This observation 
is corroborated by the overall clustering and mean degree coefficients reported in Table 1.

Table 1. Clustering and mean degree statistics regarding in the AUC's shared departmental presence network.

\begin{tabular}{lll}
\hline Network & Global clustering & Mean degree \\
\hline \hline AUC's shared departmental presence network & 0.78 & 8.62 \\
\hline Source: Own elaboration & & \\
\hline
\end{tabular}

The clustering coefficient, which takes the value of 0.78 , indicates a not-so-tight structure among blocks on the network. Additionally, the mean degree of the network is just 8.62, a lower value when compared with that of the FARC, as we will show later. Based on these statistics we would expect high levels of remilitarization for the AUC.

Information about the remilitarized blocks of the AUC is presented in Table 2.

Table 2. AUC’s remilitarized blocks.

\begin{tabular}{ll}
\hline AUC's Block & Block label \\
\hline \hline Bloque Heroes de Tolová & 11 \\
Bloque Libertadores del Sur & 13 \\
Autodefensas Campesinas de Meta y Vichada & 15 \\
Bloque Pacífico & 16 \\
Bloque Centauros & 17 \\
BCB Vichada & 19 \\
Bloque Tolima & 20 \\
BCB Martires de Guatica & 22 \\
Bloque Vencedores de Arauca & 23 \\
Bloque Andaquies & 29 \\
BCB Sur del Putumayo & 30 \\
Heroes del Llano y Guaviare & 33 \\
Heroes del Llano y Guaviare & 34 \\
Bloque Élmer Cardenas - Turbo & $37 \mathrm{a}$ \\
Bloque Élmer Cardenas - Ungia & $37 \mathrm{~b}$ \\
Bloque Élmer Cardenas - Necolí & $37 \mathrm{c}$ \\
Bloque Catatumbo & 6 \\
Bloque Calima & 7 \\
Bloque Cordoba & 8 \\
Bloque Suroeste Antioqueño & 9 \\
\hline Source: Zukerman (2016) & \\
\hline
\end{tabular}

According to this information, 20 out of the total 39 blocks of the AUC, corresponding to 51\%, remilitarized. Altogether, this results provide evidence in favor of H1, stipulating that low levels of cohesion among blocks on the network are associated with higher risks of remilitarization. 
We also find evidence supporting $\mathrm{H} 2$ by looking at the number of isolated or grouped in smaller components on the network that remilitarize. We find that 12 out of the total 15 blocks in isolated or smaller components eventually have remilitarized, corresponding to a rate of $80 \%$.

We now turn to the role played by central military units on the network within the success of the DDR process by testing H3, positing that more central military units increase the success of the DDR process if they do not remilitarize. Table 3 reports basic descriptive statistics of centrality for each military unit.

Table 3*. Centrality statistics regarding the AUC's shared departmental presence network.

\begin{tabular}{|c|c|c|c|c|}
\hline AUC's Block & $\begin{array}{l}\text { Block } \\
\text { label }\end{array}$ & $\begin{array}{l}\text { Overall } \\
\text { bidirectional } \\
\text { degree }\end{array}$ & $\begin{array}{l}\text { Overall } \\
\text { simple } \\
\text { degree }\end{array}$ & $\begin{array}{l}\text { Betweenness } \\
\text { centrality }\end{array}$ \\
\hline BCB Nordeste Antioqueño & 21 & 26 & 13 & 120 \\
\hline Autodefensas Campesinas del Magadalena Medio & - & & & \\
\hline Puerto Triunfo & 28 & 26 & 13 & 81 \\
\hline Bloque Norte & 32 & 18 & 9 & 80 \\
\hline Bloque Élmer Cárdenas - Necolí & $37 c$ & 22 & 11 & 42 \\
\hline Bn Front Hector Julio Peinado & 31 & 4 & 2 & 22 \\
\hline Autodefensas Campesinas de Meta y Vichada & 15 & 6 & 3 & 2 \\
\hline Bloque Centauros & 17 & 6 & 3 & 2 \\
\hline Bloque Cacique Nutibara & 1 & 18 & 9 & 0 \\
\hline Bloque La Mojana & 10 & 10 & 5 & 0 \\
\hline Bloque Héroes de Tolová & 11 & 4 & 2 & 0 \\
\hline Bloque Héroes de Monte de María & 12 & 8 & 4 & 0 \\
\hline Bloque Héroes de Granada & 14 & 18 & 9 & 0 \\
\hline Bloque Pacífico & 16 & 6 & 3 & 0 \\
\hline Bloque Noroccidente Antioqueño & 18 & 18 & 9 & 0 \\
\hline BCB Vichada & 19 & 2 & 1 & 0 \\
\hline Autodefensas Campesinas de Ortega & 2 & 4 & 2 & 0 \\
\hline Bloque Tolima & 20 & 2 & 1 & 0 \\
\hline BCB Mártires de Guática & 22 & 6 & 3 & 0 \\
\hline Bloque Vencedores de Arauca & 23 & 4 & 2 & 0 \\
\hline Bloque Mineros & 24 & 18 & 9 & 0 \\
\hline Autodefensas Campesinas del Magadalena Medio & - & & & \\
\hline Puerto Boyacá & 25 & 2 & 1 & 0 \\
\hline BCB Sur de Bolivar & 26 & 8 & 4 & 0 \\
\hline Bloque Resistencia Tayrona & 27 & 6 & 3 & 0 \\
\hline Bloque Bananero & 3 & 18 & 9 & 0 \\
\hline Héroes del Llano y Guaviare & 33 & 6 & 3 & 0 \\
\hline Héroes del Llano y Guaviare & 34 & 6 & 3 & 0 \\
\hline Cacique Pipintá & 35 & 6 & 3 & 0 \\
\hline Autodefensas Campesinas del Casanare & 36 & 4 & 2 & 0 \\
\hline Bloque Élmer Cárdenas - Turbo & $37 a$ & 18 & 9 & 0 \\
\hline Bloque Sur del Magdalena & 4 & 2 & 0 & \\
\hline Bloque Cundinamarca & 5 & 2 & 1 & 0 \\
\hline Bloque Catatumbo & 6 & 2 & 1 & 0 \\
\hline Bloque Calima & 7 & 6 & 3 & 0 \\
\hline
\end{tabular}


Table 3 and Figure 1 reveal that blocks 21, 28 and 32 have the highest centrality measures and to be located on the main component of the AUC's network structure. Interestingly, neither of these blocks remilitarized nor most of the military units in the same component. Only 8 out of the 24 blocks in the same component, corresponding to $33 \%$, eventually remilitarize. Further, when looking at the graph, one could argue that most of the 8 blocks that remilitarized are located at the periphery of the network, where less control can be exerted. These findings provide support in favor of $\mathrm{H3}$.

Finally, according to $\mathrm{H} 4$, military units in isolated or smaller components and working on well-identified areas associated with the drug trafficking business are more likely to remilitarize. Table 4 lists the departments with a history of high coca production. We use this information to identify military units located on well-identified areas associated with drug production and trafficking. Figure 2 presents a map including drug trafficking business characteristic for the military units.

Table 4. Coca production-related departments.

\begin{tabular}{l}
\hline Departments \\
\hline \hline Nariño \\
Putumayo \\
Caquetá \\
Cauca \\
Guaviare \\
Meta \\
Antioquia \\
Chocó \\
Vichada \\
Bolívar \\
Córdoba \\
Norte Santander \\
Source: United Nations Office on Drugs and Crime -UNODC. \\
\hline
\end{tabular}


Figure 1. AUC's drug production/trafficking and shared departmental presence network. (Gray nodes indicate military units in areas with drug production)

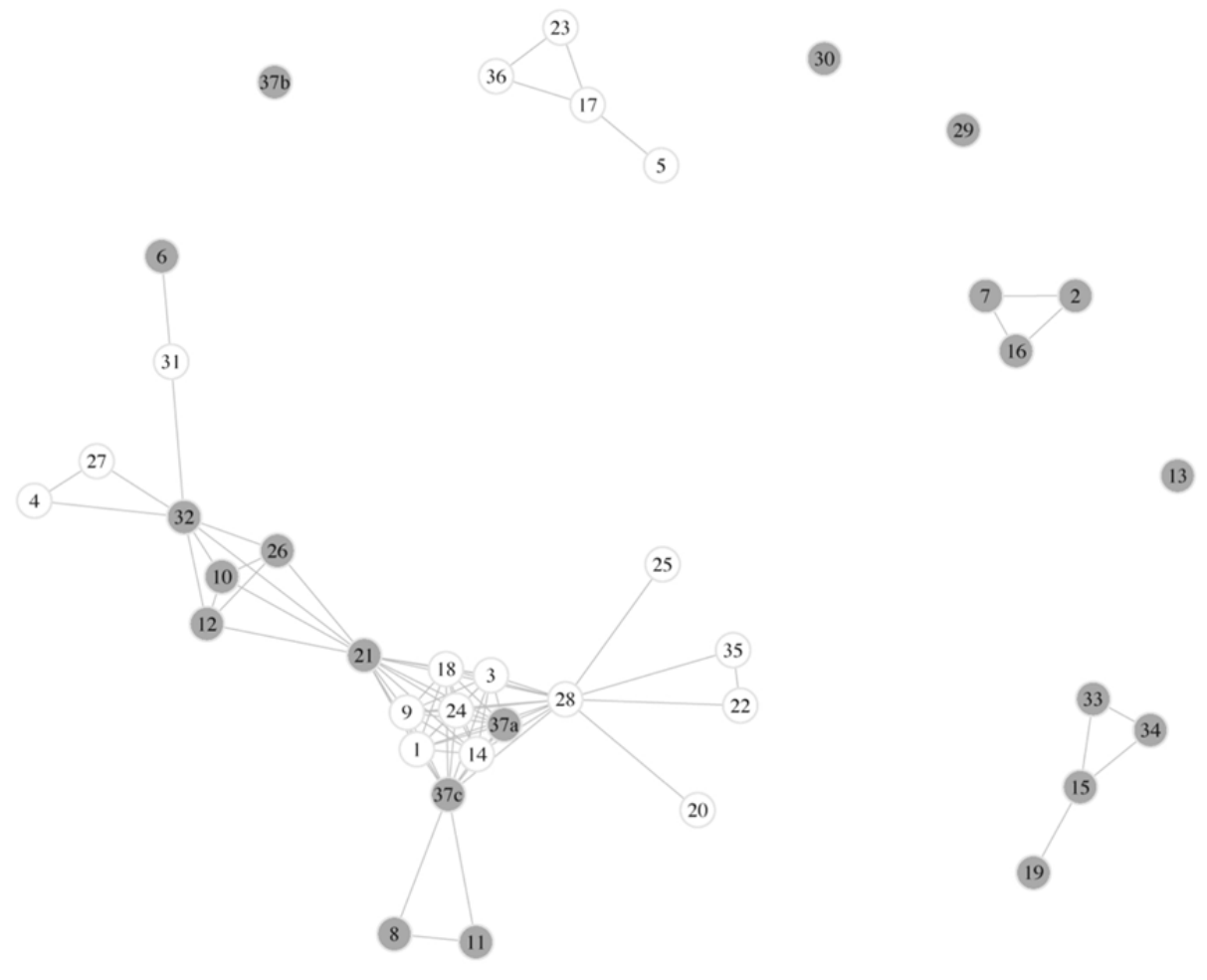

As it can be seen from Figure 2, most of the remilitarized blocks of the AUC are located precisely in areas associated with drug trafficking business, and are linked to other military units with the same characteristic. We find that 15 out of the total 20 blocks that remilitarized, 75\%, are located in areas associated with drug trafficking business. We also compute the assortativity coefficient for three different characteristics 
of the nodes, i.e., drug production/trafficking, type of recruitment and remilitarization, and find that the first of these attributes exhibits the greater assortativity coefficient, 0.58. This means that military units on the network tend to link more to other units sharing the drug production/trafficking characteristic. This finding provides support in favor of H4.

\section{Network Structure and the Possible Remilitarization of the FARC}

Figure 3 shows the network structure for the FARC, based on the shared departmental presence attribute for their military units as explained above.

Figure 3. FARC’s shared departmental presence sub-network.

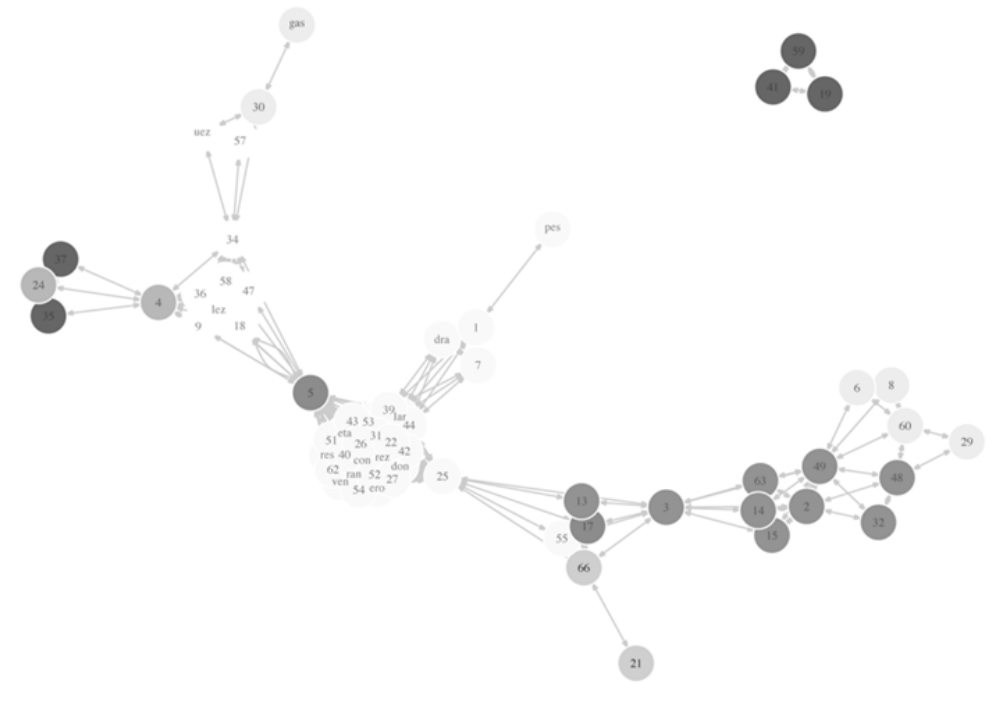

Figure 4. FARC’s Shared departmental presence sub-network color codes. ${ }^{14}$

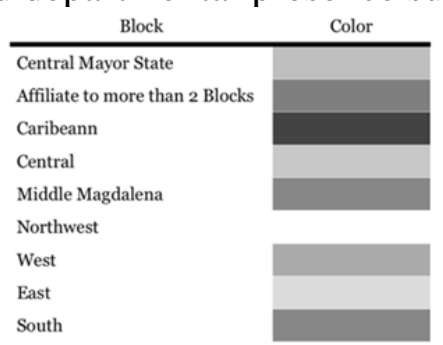


Again, we start with a visual inspection of the graph in Figure 3. This time the graph tells us that the FARC's network is composed by only 4 components, and the biggest component includes almost all of the military units. This suggests a more cohesive network. The overall clustering coefficient of the network is 0.92 , and this corroborates the conclusion that this network is tighter than the AUC network discussed previously. Thus, based on H1, we should expect less remilitarization for the FARC after an eventual DDR.

Even though there has not yet been a DDR process with the FARC, we can evaluate the model prediction against information about the FARC's fronts themselves and resistance to the actual peace negotiations as well as expert testimony on the possible fronts that may act as spoilers of the peace process. ${ }^{15}$ With regards to the latter, the Colombian newspaper El País has published a list of 13 fronts considered to be the most likely spoilers in a worst case scenario, displayed in Figure 5.

Figure 5. FARC’s potential dissidents. 


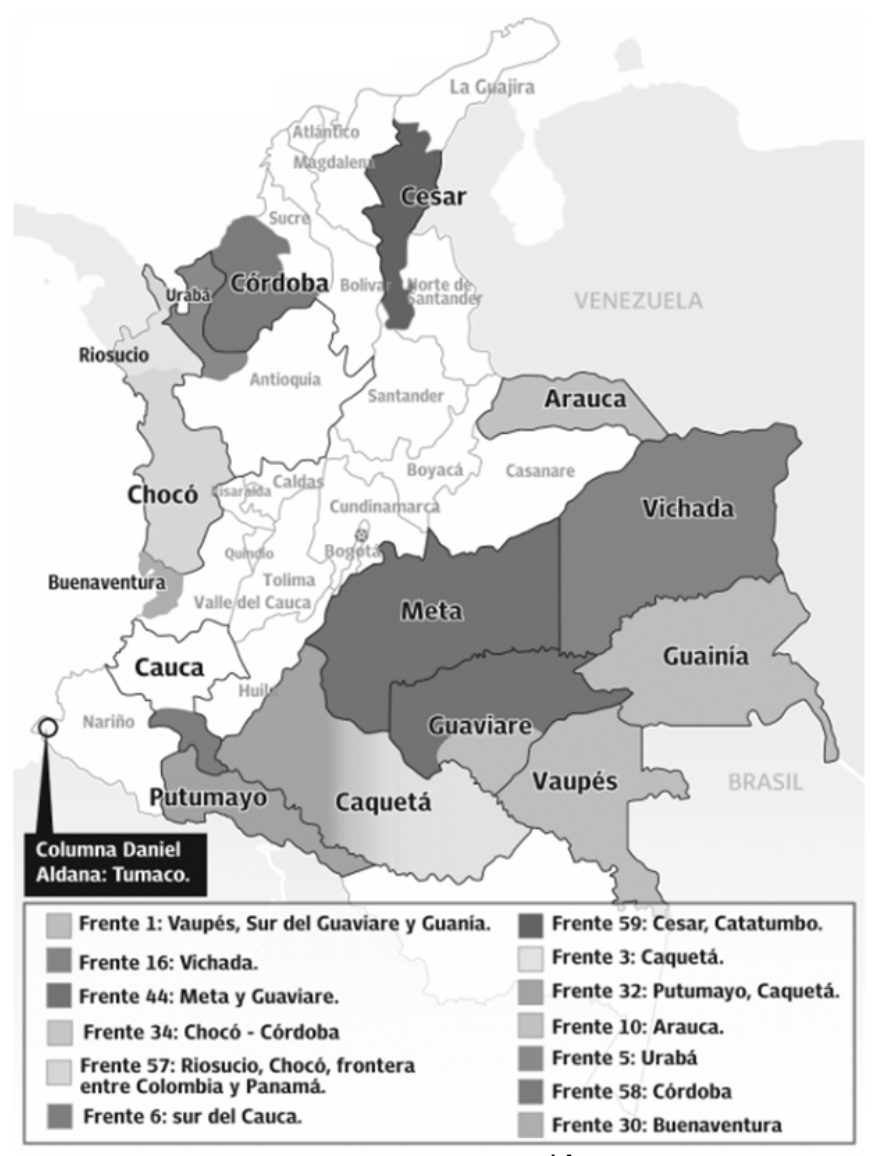

Source: El País. ${ }^{16}$

We note that even if this worst case scenario were to materialize only $18 \%$ of the fronts of the FARC would remilitarize. This is consistent with our prediction that FARC units would be more robust to remilitarization than the AUC, and we conclude that is consistent with what we would expect from H1.

When looking at the fronts in smaller components of the network and its probable remilitarization there seems to be no support in favor of $\mathrm{H} 2$, as only 3 out of the list of 13 dissident fronts are located on smaller components. However, there are at least 4 other fronts of the dissident list located at the periphery of the network (fronts 30, 57, 1 and 6) where it is expected to be less control and coercive capacity. Moreover, the existence of a hierarchical links between nodes should be taking into account. To see this, we include the hierarchical structure of the FARC in the network and obtain what we called the complete network of the FARC, see Figure 6. This complete 
network includes both the shared departmental presence and the organizational hierarchical structure of the group. If we include this hierarchical relationship between military units then there are no isolated agents or smaller components any more. Thus, although several units are located at the periphery of the network, the hierarchical links may be much stronger than the link of shared departmental presence for these peripheral military units.

Figure 6. FARC’s full network. ${ }^{17}$

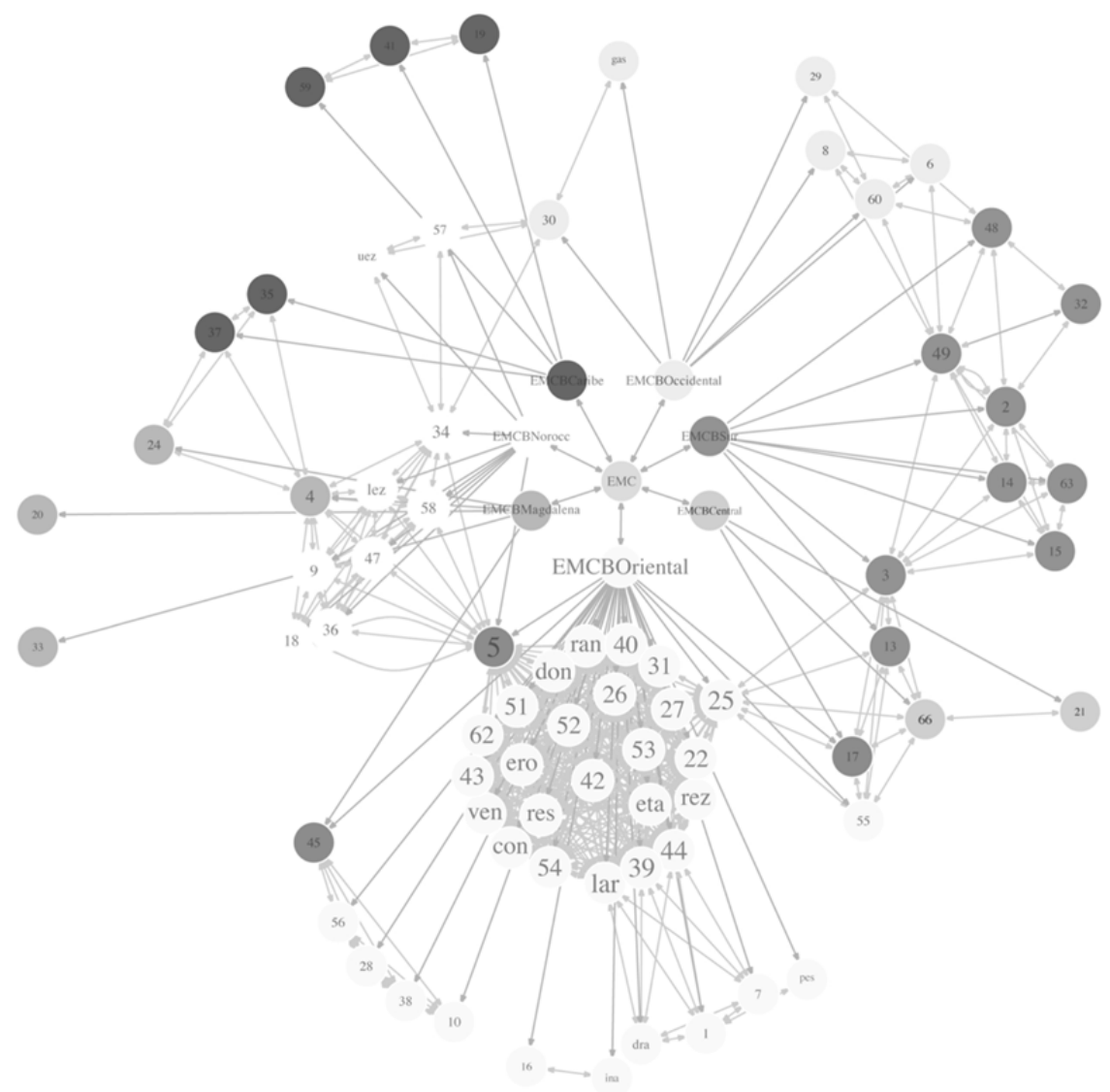

We now turn to the role of central nodes within the success of an eventual DDR process with the FARC. Table 5 reports the centrality measures for the military units in the network of shared departmental presence of the FARC. 
Table 5. Top ten centrality statistics regarding the FARC's shared departmental presence network.

\begin{tabular}{llll}
\hline FARC's front & $\begin{array}{l}\text { Overall } \\
\text { bidirectional } \\
\text { degree }\end{array}$ & $\begin{array}{l}\text { Overall } \\
\text { simple } \\
\text { degree }\end{array}$ & $\begin{array}{c}\text { Betweenness } \\
\text { centrality }\end{array}$ \\
\hline \hline Frente 25 & 58 & 29 & 1462 \\
Frente 5 & 66 & 33 & 1350 \\
Frente 3 & 20 & 10 & 1078 \\
Frente 49 & 22 & 11 & 507 \\
Frente 34 & 22 & 11 & 448 \\
Frente 4 & 22 & 11 & 342 \\
Frente 39 & 58 & 29 & 144 \\
Frente 44 & 58 & 29 & 144 \\
Frente Reinaldo Cuellar & 58 & 29 & 144 \\
Frente 2 & 16 & 8 & 141 \\
\hline Source: Own elaboration & & & \\
\hline
\end{tabular}

We find that fronts 25, 5 and 3 have the highest centrality measures. According to H3, these three fronts are relevant for the success of a hypothetical DDR process if they decide not to remilitarize. Unfortunately, Fronts 5 and 3 are listed as dissident fronts. This result highlights the tension between hierarchy organizational and shared departmental presence type of links. In fact, agents such as front 25 allow processes of transmission of information to be carried out among military-type agents without incorporating restrictions coming from the chain of management of the guerrilla.

However, different links can have variable influence, and we acknowledge that the final predictions about the risk of remilitarization could differ depending on the particular weights that are assigned to different links. For instance, we appreciate that the degree to which the organizational structure of the FARC is capable of exercise tight control over its sub-ordinates could also depend on different factors such as the idiosyncratic characteristics of the leaders and their ability to motivate individual recruits and enhance collective morale. Thus, if the influence of the hierarchical relationship between nodes by far overwhelms the relative weight of the shared departmental presence, then we would expect to see a lower risk of remilitarization. 
Finally, we identify military units that are located on well identified areas associated with the drug trafficking business and map them into the network. The result of this exercise is presented in Figure 7. It can be seen from the figure that most of the fronts located in areas associated with the drug trafficking business are linked to others with this same attribute. In fact, the assortativity coefficient when considering drug production/trafficking as the relevant characteristic is 0.67 . This means that drug production/trafficking is a critical issue for the success of an eventual DDR process. If most of the central nodes decide to accept and stand by the negotiations then we would expect most other units also not to remilitarize. 
Figure 7. FARC's drug production/trafficking and shared departmental presence network.

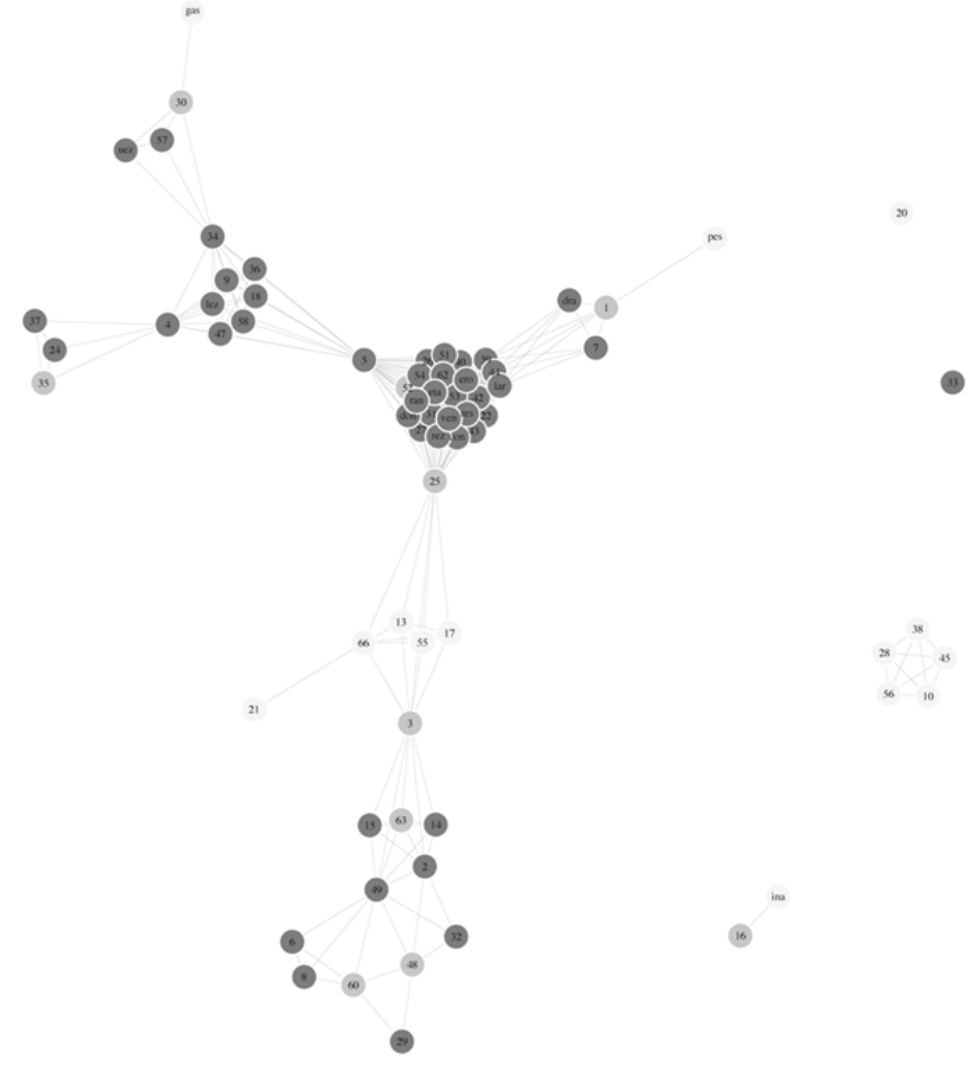

(Black nodes indicate military units with complete presence in areas with drug production, grey nodes indicate military units with partial presence in areas with drug production and white nodes indicate military units with no presence in areas with drug production.)

\section{Conclusions}

We have highlighted the importance of analyzing the network structure of an insurgent group in order to understand the prospects for success in DDR processes and the specific cases where the challenges are likely to be more severe. We map the network structure of the AUC and the FARC and explore the relationship between some basic characteristics of their network structures and the success of DDR processes. We find that armed military units grouped in small size components or located at the periphery of the network remilitarize with higher probability with respect to other units. We 
identify military units for each group with high degree of centrality and analyze their role on the success of the DDR process. We also find that military units located on areas related to drug production/trafficking require special attention considering that units sharing this characteristic have a high probability to remilitarize. Although it is difficult to predict, especially about the future, we believe that the findings presented for observed recidivism for the AUC attest to how the predictions of the model provides insights for the possible challenges in a DDR process involving the FARC.

\section{Notes}

1. Humphreys and Weinstein, "Demobilization and reintegration.” 532.

2. Cunningham, Gleditsch, and Salehyan, "It Takes Two"; Staniland, Networks of Rebellion. 579 - 586.

3. Zukerman, Organized Violence.

4. Jackson, Social and Economic Networks.

5. Brams, "Transaction flows”; Schofield, “A topological model.”

6. Cranmer, Menninga, and Mucha, "Kantian Fractionalization”; Kinne, "Multilateral Trade.”

7. Brams, "Trade in the north area”; Kinne, "Network Dynamics.”

8. The detailed organizational structure of the FARC is in CNMH, Guerrilla $y$ población civil. 82.

9. For details see Newman, “Assortative Mixing in Networks.” 1.

10. Oficina del Alto Comisionado para la Paz, Proceso de Paz.

11. Ibid.; Zukerman, Organized Violence. 106 - 109.

12. CNMH, Guerrilla y población civil. 76 - 82.

13. ODDR, "Presencia de Organizaciones Guerrilleras.” 5 - 15.

14. The category Affiliate to more than two blocks, in the color codes, indicates fronts that in the same year were present in at least two areas under the control of different blocks.

15. El País, "Disidencias.”

16. Ibid.; El país, "Disidencias."

17. The complete network of the FARC involves 944 connections, out of which 868 are reciprocal and 76 are non-reciprocal. Also, at least 12 double connections are 
evident, which are relationships of shared departmental presence between militarytype agents with more than one common zone of operation.

\section{Acknowledgements}

Ernesto Cardenas acknowledges support from the British Council, Researcher Links Travel Grant BC 031 EDU2016 (ID 216421661).

\section{Compliance with Ethical Standards}

Conflict of Interest: The authors declare that they have no conflict of interest.

\section{References}

Brams, Steven J. “Transaction flows in the international system.” American Political Science Review 60, (1966a): 880-898.

Brams, Steven J. "Trade in the north area: An approach to the analysis of transformations in a system.” Peace Research Society Papers 6, (1966b): 143164.

CNMH, Centro Nacional de Memoria Histórica. Guerrilla y población civil, trayectoria de las FARC 1949-2013 [Guerrilla and civil population, trayectory of the FARC 1949-2013]. Tercera Edición. Bogotá: CNMH, 2014.

Cranmer, Skyler J., Elizabeth J. Menninga, and Peter J. Mucha. “Kantian Fractionalization Predicts the Conflict Propensity of the International System.” Proceedings of the National Academy of Sciences of the United States of America 112, no. 38 (2015): 11812-11816.

Cunningham, David E., Kristian Skrede Gleditsch, and Idean Salehyan. "It Takes Two: A Dyadic Analysis of Civil War Duration and Outcome.” The Journal of Conflict Resolution 53, no. 4 (2009): 570-597. 
El País. “Estos son los frentes donde podría haber disidencias de las FARC.” El País, July 10, 2016, http://www.elpais.com.co/elpais/colombia/proceso-paz/ noticias/estos-son-frentes-farc-firmarian-paz.

Humphreys, Macartan and Jeremy Weinstein. “Demobilization and reintegration.” Journal of Conflict Resolution 51, no. 4 (2007): 531-567.

Jackson, Matthew O. Social and Economic Networks. Princeton university press, 2010.

Kinne, Brandon J. "Multilateral Trade and Militarized Conflict: Centrality, Openness, and Asymmetry in the Global Trade Network.” The Journal of Politics 74, no. 1 (2012): 308-322.

Kinne, Brandon J. "Network Dynamics and the Evolution of International Cooperation.” The American Political Science Review 107, no. 4 (2013): 766785.

Newman, Mark E J. “Assortative Mixing in Networks.” Physical Review Letters 89, no. 20 (2002): 2087011-2087014.

ODDR, Observatorio de Procesos de Desarme Desmovilización y Reintegración/ Universidad Nacional de Colombia. "Presencia de Organizaciones Guerrilleras y Bacrim en Territorio Colombiano en 2012 [Presence of Guerrilla Organizations and Bacrim in the Colombian Territory in 2012].” 2012.

Oficina Alto Comisionado para la Paz. Proceso de Paz con las Autodefensas: Informe Ejecutivo [Peace Process with the Self-Defense: Executive Report]. Presidencia de la República, 2006.

Schofield, Norman J. “A topological model of international relations.” Peace Reserach Society Papers 18, (1972): 93-112.

Staniland, Paul. Networks of Rebellion, Explaining Insurgent Cohesion and Collapse. Cornell University Press, 2010.

Zukerman, Sarah. Organized Violence after Civil War: The Geography of Recruitment in Latin America. Cambridge University Press, 2016. 


\section{Appendix}

Table 6. AUC's Blocks

\begin{tabular}{|c|c|}
\hline Block & Label \\
\hline Bloque Cacique Nutibara & 1 \\
\hline Autodefensas Campesinas de Ortega & 2 \\
\hline Bloque Bananero & 3 \\
\hline Bloque Sur del Magdalena & 4 \\
\hline Bloque Cundinamarca & 5 \\
\hline Bloque Catatumbo & 6 \\
\hline Bloque Calima & 7 \\
\hline Bloque Córdoba & 8 \\
\hline Bloque Suroeste Antioqueño & 9 \\
\hline Bloque La Mojana & 10 \\
\hline Bloque Héroes de Monte de María & 12 \\
\hline Bloque Héroes de Tolová & 11 \\
\hline Bloque Libertadores del Sur & 13 \\
\hline Bloque Héroes de Granada & 14 \\
\hline Autodefensas Campesinas de Meta y Vichada & 15 \\
\hline Bloque Pacífico & 16 \\
\hline Bloque Centauros & 17 \\
\hline Bloque Noroccidente Antioqueño & 18 \\
\hline BCB Vichada & 19 \\
\hline Bloque Tolima & 20 \\
\hline BCB Nordeste Antioqueño & 21 \\
\hline BCB Martires de Guática & 22 \\
\hline Bloque Vencedores de Arauca & 23 \\
\hline Bloque Mineros & 24 \\
\hline Autodefensas campesinas del Magadalena Medio - Puerto Boyacá & 25 \\
\hline BCB sur de Bolívar & 26 \\
\hline Bloque Resistencia Tayrona & 27 \\
\hline Autodefensas Campesinas del Magadalena Medio - Puerto Triunfo & 28 \\
\hline Bloque Andaquies & 29 \\
\hline BCB Sur del Putumayo & 30 \\
\hline BN Front Héctor Julio Peinado & 31 \\
\hline Bloque Norte & 32 \\
\hline Héroes del Llano y Guaviare & 33 \\
\hline Héroes del Llano y Guaviare & 34 \\
\hline Cacique Pipintá & 35 \\
\hline Autodefensas Campesinas del Casanare & 36 \\
\hline Bloque Élmer Cárdenas - Turbo & $37 a$ \\
\hline Bloque Élmer Cárdenas - Ungia & $37 b$ \\
\hline Bloque Élmer Cárdenas - Necolí & $37 \mathrm{c}$ \\
\hline
\end{tabular}


Table 7. FARC's fronts I

\begin{tabular}{|c|c|}
\hline Front & Label \\
\hline Frente Vladimir Stiven & ven \\
\hline Frente Aurelio Rodríguez & uez \\
\hline Frente Esteban Ramírez & rez \\
\hline Frente Camilo Torres & res \\
\hline Frente Manuela Beltrán & ran \\
\hline Frente Vaupés & pes \\
\hline Frente Mario Vélez & lez \\
\hline Frente Reinaldo Cuellar & lar \\
\hline Frente Acacio Medina & ina \\
\hline Frente Manuel Cepeda Vargas & gas \\
\hline Frente Policarpa Salavarrieta & eta \\
\hline Frente Abelardo Romero & ero \\
\hline Frente Víctor Saavedra & dra \\
\hline Frente Urías Rondón & don \\
\hline Frente Felipe Rincón & con \\
\hline Frente 66 & 66 \\
\hline Frente 63 & 63 \\
\hline Frente 62 & 62 \\
\hline Frente 60 & 60 \\
\hline Frente 59 & 59 \\
\hline Frente 58 & 58 \\
\hline Frente 57 & 57 \\
\hline Frente 56 & 56 \\
\hline Frente 55 & 55 \\
\hline Frente 54 & 54 \\
\hline Frente 53 & 53 \\
\hline Frente 52 & 52 \\
\hline Frente 51 & 51 \\
\hline Frente 49 & 49 \\
\hline Frente 48 & 48 \\
\hline
\end{tabular}

Table 8. FARC’s fronts I I

\begin{tabular}{ll}
\hline Front & Label \\
\hline \hline Frente 47 & 47 \\
Frente 45 & 45 \\
Frente 44 & 44 \\
Frente 43 & 43
\end{tabular}


Frente 42

Frente 41

Frente 40

Frente 39

Frente 38

Frente 37

Frente 36

Frente 35

Frente 34

Frente 33

Frente 15

Frente 13

Frente 10

Frente 9

Frente 8

Frente 7

Frente 6

Frente 5

Frente 4

Frente 3

Frente 2

Frente 1

Frente 32

Frente 16

Frente 31

Frente 30

Frente 29

Frente 28

Frente 27

Frente $26 \quad 26$

Frente 25

Frente $24 \quad 24$

Frente $22 \quad 22$

Frente $21 \quad 21$

Frente $20 \quad 20$

Frente $19 \quad 19$

Frente $18 \quad 18$

$\begin{array}{ll}\text { Frente } 17 & 17\end{array}$

Frente $14 \quad 14$

Estado Mayor Central $\quad$ EMC

Estado Mayor Central del Bloque Caribe $\quad$ EMCBCaribe

Estado Mayor Central del Bloque Central $\quad$ EMCBCentral

Estado Mayor Central del Bloque Magdalena $\quad$ EMCBMagdalena

Estado Mayor Central del Bloque Noroccidental $\quad$ EMCBNorocc

Estado Mayor Central del Bloque Occidental $\quad$ EMCBOccidental

Estado Mayor Central del Bloque Oriental EMCBOriental

Estado Mayor Central del Bloque Sur $\quad$ EMCBSur

Source: ODDR (2012) 